\title{
GENETIC CORRELATION BETWEEN TRAITS IN THE ESALQ-PB1 MAIZE POPULATION DIVERGENTLY SELECTED FOR TASSEL SIZE AND EAR HEIGHT
}

\author{
Austeclínio Lopes Farias Neto; José Branco de Miranda Filho* \\ ${ }^{1}$ Embrapa Cerrados, Rodovia BR 020, km 17 - CEP: 73301-970 - Planaltina, DF. \\ ${ }^{2}$ Depto. de Genética - USP/ESALQ, C.P. 83 - CEP: 13400-970 - Piracicaba, SP. \\ *Autor correspondente <jbmirand@carpa.ciagri.usp.br>
}

\begin{abstract}
Full-sib and selfed $\left(S_{1}\right)$ progenies were obtained from sub-populations of ESALQ-PB1, divergently selected for tassel size ( $T+$ and $T-)$ and ear height $(E+$ and $E-)$, and used for estimating genetic and phenotypic correlation coefficients between traits. The analyzed traits were: EW- total ear weight (g/plant), $\mathrm{PH}$ - plant height $(\mathrm{cm})$, EH- ear height $(\mathrm{cm})$, TB- tassel branch number and TL- tassel length. The highest genetic $\left(r_{G}\right)$ and phenotypic $\left(\mathrm{r}_{\mathrm{F}}\right)$ correlation was observed for the combination $\mathrm{PH} \times \mathrm{EH}$, as expected, with average of 0.800 and 0.778 , respectively over sub-populations and locations. It is apparent that divergent selection for tassel size did not affect greatly the correlation between $\mathrm{PH}$ and $\mathrm{EH}$ in the full sib progenies, but in the inbred progenies the correlation was smaller in the sub-population selected for larger tassels. Genetic correlation between PH and EH with tassel traits was always positive but ranged from 0.020 to 0.668 in Piracicaba and from 0.06 to 0.309 in Rio Verde. Genetic correlation between PH and EH with yield (EW) also was positive in the range of 0.087 to 0.503 . EH showed higher correlation with $\mathrm{EW}$ in relation to $\mathrm{PH} \times \mathrm{EW}$ and differences were larger in the sub-populations divergently selected for ear height. Correlation between tassel traits with other traits was positive in most of instances and a lack of consistency was observed among sub-populations. Generally the coefficients of genetic and phenotypic correlation differed substantially from the estimates in the base population ESALQ-PB1 before divergent selection for tassel size and ear placement. Divergent selection affected the correlation between traits under unpredicted and varying magnitudes.
\end{abstract}

Key words: Zea mays, genetic correlation, divergent selection, tassel size, ear height

\section{CORRELAÇÃO GENÉTICA ENTRE CARACTERES NA POPULAÇÃO DE MILHO ESALQ-PB1 APÓS SELEÇÃO DIVERGENTE PARA TAMANHO DO PENDÃO E ALTURA DA ESPIGA}

\begin{abstract}
RESUMO: Progênies de irmãos germanos e de autofecundação $\left(S_{1}\right)$ foram obtidas de sub-populações de ESALQPB1 após seleção divergente para tamanho do pendão $(T+$ e $T-)$ e altura da espiga $(E+$ e $E-)$ e utilizadas para estimar os coeficientes de correlação genética e fenotípica entre caracteres. Foram analisados os caracteres: EWpeso de espigas (g/planta), $\mathrm{PH}$ - altura da planta $(\mathrm{cm})$, EH- altura da espiga $(\mathrm{cm})$, TB- número de ramificações do pendão e TL- comprimento do pendão. Como esperado, as maiores correlações genéticas $\left(r_{G}\right)$ e fenotípicas $\left(r_{F}\right)$ foram observadas para a combinação $\mathrm{PH} \times \mathrm{EH}$, com médias de 0,800 e 0,778, respectivamente, em várias subpopulações e locais. Aparentemente, a seleção divergente para tamanho do pendão não afetou fortemente a correlação entre $\mathrm{PH}$ e EH nas progênies de irmãos germanos, mas nas progênies endogâmicas a correlação foi menor na sub-população selecionada para pendão grande. A correlação genética entre $\mathrm{PH}$ e EH com os caracteres do pendão foram sempre positivas mas variaram de 0,020 a 0,068 em Piracicaba e de 0,060 a 0,309 em Rio Verde. A correlação genética entre $\mathrm{PH}$ e EH com produção (EW) também foi positiva, na faixa de 0,087 a 0,503. EH mostrou maior correlação com EW em relação a $\mathrm{PH} \times \mathrm{EW}$ e as diferenças foram maiores nas sub-populações que sofreram seleção divergente para altura da espiga. A correlação entre os caracteres do pendão com outros caracteres foi positiva na maioria dos casos e uma falta de consistência foi observada entre sub-populações. Em geral, os coeficientes de correlação genética e fenotípica diferiram substancialmente das estimativas na população base ESALQ-PB1 antes da seleção divergente para tamanho do pendão e posição da espiga. A seleção divergente afetou a correlação entre caracteres sob magnitudes imprevisíveis e variáveis.

Palavras-chave: Zea mays,correlação genética, seleção divergente, tamanho do pendão, altura da planta
\end{abstract}

\section{INTRODUCTION}

Maize (Zea mays L.) is, among the cultivated species, one that has undergone a fantastic improvement in yield through artificial selection (Hallauer \& Miranda Filho, 1995). Cultural practices also have greatly contributed to increase yield in the maize crops during this century. More recently, attention has been given to plant architecture toward a better efficiency in the utilization of solar energy and photosynthetic capacity (Donald, 1968; Wittner, 1974; Paterniani, 1974, 1981; Miranda Filho, 1974; Sampaio, 1986). Also, intentionally or not, changes have occurred in tassel size for a better utilization of photosynthates (Mock \& Pearce, 1975). 
The association between traits is an important aspect to deal with in breeding programs, because genetic change in a given trait may change positively or negatively other traits (Vencovsky \& Barriga, 1992). In addition, in most breeding programs the strategy is based on selection for several traits simultaneously and, therefore, knowledge on the genetic association between traits is inevitably useful for the establishment of selection criteria. The basic causes of genetic correlation are pleiotropy, and linkage disequilibrium (Falconer, 1964; Vencovsky, 1978; Hallauer \& Miranda Filho, 1995).

One important application of the genetic correlation in breeding programs refers to indirect selection for traits of low heritability and consequently low direct response to selection. Selection for another trait may result in indirect response in the low heritable trait, provided the following conditions are satisfied: i) traits under consideration must be highly correlated genetically; ii) heritability of the secondary trait must be higher than the trait of higher interest (Falconer, 1964; Vencovsky \& Barriga, 1992). In maize, for example, two secondary traits were identified for indirect selection to increase yield: prolificacy (Paterniani, 1981) and tassel size (Geraldi et al., 1985).

Although many authors have referred to a negative association between tassel size and yield potential (Leonard \& Kiesselbach, 1932; Hunter et al., 1973; Fakorede \& Mock, 1978; Lordelo \& Miranda Filho, 1981; Geraldi et al., 1985), positive association of those traits also have been reported (Lordelo \& Miranda Filho, 1981; Sampaio, 1986; Soares Filho, 1987). There are evidences that the correlation between yield and tassel size tends to be higher and negative under stresses caused by unfavorable environments (Soares Filho, 1987). Brunini et al. (1983) emphasized that environmental factors such as photoperiod, solar radiation and rainfall affect decisively the yield potential of a corn crop and consequently the association between traits may change if there is a differentiated variety response to the environmental factors.

Souza Júnior et al. (1985) reported on a negative correlation between tassel size and prolificacy which were explained by a larger amount of indol-acetic-acid (IAA) produced by larger tassels and causing inhibition of prolificacy, or vice-versa (Anderson, 1967). Other studies referring to the correlation of tassel size with other characters are sometimes contradictories. The correlation between tassel branch number with plant height, ear height and ear placement was reported as positive by Obilana \& Hallauer (1974), Ayala Osuna et al. (1986); Miranda Filho \& Andrade (2000). However, the same associations were positive in some cases and negative in other cases, as reported by Lordelo (1982), Aguilar Morán (1984), Sampaio (1986), Soares Filho (1987), and Araújo (1992). Some estimates of additive and phenotypic correlation between tassel branch number with plant height, ear height, and grain yield are summarized in TABLE 1 . The objectives of this work was to study changes in the genetic correlation between traits after divergent selection for tassel size and
TABLE 1 - Ranges for the estimates of $r_{A}$ (additive genetic correlation) and $r_{F}$ (phenotypic correlation, family means) of tassel branch number and other quantitative traits (plant height, ear height, and grain yield).

\begin{tabular}{cccccc}
\hline Characters & \multicolumn{2}{c}{$\begin{array}{c}N^{\circ} \text { of } \\
\text { estimates }\end{array}$} & \multicolumn{2}{c}{ Range } & Average \\
\hline Plant height & $\mathrm{r}_{\mathrm{A}}$ & 13 & -0.184 to 0.363 & 0.054 \\
& $\mathrm{r}_{\mathrm{F}}$ & 17 & -0.111 to 0.289 & 0.138 \\
Ear height & $\mathrm{r}_{\mathrm{A}}$ & 13 & -0.269 to 0.436 & 0.108 \\
& $\mathrm{r}_{\mathrm{F}}$ & 17 & -0.037 to 0.308 & 0.204 \\
Grain yield & $\mathrm{r}_{\mathrm{A}}$ & 13 & -0.642 to 0.112 & -0.197 \\
& $\mathrm{r}_{\mathrm{F}}$ & 20 & -0.339 to 0.290 & -0.046 \\
\hline
\end{tabular}

ear height in the maize population ESALQ-PB1.

\section{MATERIAL AND METHODS}

Four sub-populations were derived from ESALQPB1, after six cycles of divergent selection for tassel size and ear height. Sub-populations were designated by

ESALQ-PB1 $\left(E_{+}\right)$: selection for increasing ear height end/or ear placement

ESALQ-PB1 (E-): selection for decreasing ear height end/or ear placement

ESALQ-PB1 $(T+)$ : selection for increasing tassel size

ESALQ-PB1 (T-): selection for decreasing tassel size

Full sib progenies were obtained through biparental crosses from each sub-population. In ESALQ-PB1 $(T+)$ and ESALQ-PB1 ( $\mathrm{T}-$ ), $\mathrm{S}_{1}$ progenies were also obtained by selfing individual plants. The six sets totaled 921 progenies that were evaluated in 18 experiments following the completely randomized block design with three replications, at Piracicaba, SP, and Rio Verde, GO. The numbers of progenies of each set in each experiment are shown in TABLE 2.

Experimental plots were represented by a single row $4.0 \mathrm{~m}$ long with 20 plants per plot $(0.20 \mathrm{~m}$ between plants) after thinning. The following traits were analyzed: $\mathrm{PH}$-plant height $(\mathrm{cm})$, EH-ear height $(\mathrm{cm})$, TB-tassel branch number, TL-tassel length $(\mathrm{cm})$, and $\mathrm{EW}$-total ear weight $(\mathrm{g} /$ plant). Except for EW, the experimental units were represented by means of three plants per plot. In Rio Verde (GO), only $\mathrm{PH}, \mathrm{EH}$ and TB of full sib progenies were evaluated.

The statistical model for variance and covariance analyses following the randomized complete block design is $Y_{i}=m+p_{i}+b_{i}+e_{i i}$, where $Y_{i j}$ is the observed mean of the $\mathrm{ith}^{\mathrm{th}}$ progeny in the $\mathrm{j}^{\text {th }}$ replication, $\mathrm{m}$ is the general mean, $p_{i}$ is the random effect of the $i^{\text {th }}$ progeny, $b$ is the random effect of the $j^{\text {th }}$ replication, and $e_{i i j}$ is the error term. In the analysis of variance the mean squares for progenies $\left(M_{p}\right)$ and Error $\left(M_{E}\right)$ have the following expectations: $E\left(M_{P}\right)=$ 
TABLE 2 - Number of full-sib (FS) or selfed $\left(S_{1}\right)$ progenies in each experiment representing six sets (divergently selected sub-populations).

\begin{tabular}{lccccccc}
\hline Sub-populations & Progeny & \multicolumn{5}{c}{ Experiments } & Total \\
\hline ESALQ-PB1 (E+) & FS & 50 & 51 & 51 & 28 & 180 \\
ESALQ-PB1 (E-) & FS & 57 & 56 & 55 & - & 168 \\
ESALQ-PB1 (T+) & FS & 55 & 54 & 56 & - & 165 \\
ESALQ-PB1 (T-) & FS & 55 & 56 & 54 & 53 & 218 \\
ESALQ-PB1 (T+) & S1 & 54 & - & - & - & 54 \\
ESALQ-PB1 (T-) & S1 & 49 & 49 & 38 & - & 136 \\
\hline
\end{tabular}

$\sigma^{2}+3 \sigma_{P}^{2}$ and $E\left(M_{E}\right)=\sigma^{2}$. In the same way, the corresponding expected mean products $\left(P_{P}\right.$ and $\left.P_{E}\right)$ in the analysis of covariance have the expectations $E\left(P_{p}\right)=c o v$ $+3 \operatorname{cov}_{P}$ and $E\left(P_{E}\right)=$ cov. In the formulations, $\sigma^{2}$ and cov refer to the variance and covariance of effects relative to the error term. In the same way, $\sigma_{\mathrm{P}}^{2}$ and $\operatorname{cov}_{\mathrm{p}}$ refer to the genetic variance and covariance relative to progeny effects. The coefficients of correlation were then calculated by

Genetic correlation coefficient -------- $r_{G}=\frac{\operatorname{cov}_{\mathrm{P}(\mathrm{XY})}}{\left[\sigma_{\mathrm{P}(\mathrm{X})}^{2} \sigma_{\mathrm{P}(\mathrm{Y})}^{2}\right]^{\frac{1}{2}}}$

Phenotypic correlation of progeny means $-r_{F}=\frac{P_{P(X Y)}}{\left[M_{P(X)} M_{P(Y)}\right]^{\frac{1}{2}}}$

$X$ and $Y$ refer to pairs of characters

\section{RESULTS AND DISCUSSION}

Observed means for six traits in sub-populations of ESALQ-PB1, divergently selected for tassel size ( $T+$ and $T-)$ and ear height ( $E+$ and $E-)$ are shown in TABLE 3. The direct effect of divergent selection on means of selected traits and the correlated response on other nonselected traits can be visualized in TABLE 3. Also, Farias Neto \& Miranda Filho (2000) already presented comparisons involving inbred and non-inbred progenies, leading to estimates of inbreeding depression. Therefore, our attention here focuses on results of genetic $\left(r_{G}\right)$ and phenotypic $\left(r_{F}\right)$ correlation (TABLE 4).

\section{Correlation between plant height (PH) and ear height (EH)}

The correlation coefficients $\left(r_{G}\right.$ and $\left.r_{F}\right)$ between $\mathrm{PH}$ and $\mathrm{EH}$ were the highest among the combinations of traits in this study. Estimates of $r_{G}$ and $r_{F}$ averaged 0.800 and 0.778 , ranging from 0.755 to 0.870 and 0.675 to 0.911 , respectively, over sub-populations and locations. It is apparent that divergent selection for tassel size did not affect greatly the correlation between $\mathrm{PH}$ and $\mathrm{EH}$ in the full sib progenies, but in the inbred progenies the correlation was smaller in the sub-population selected for larger tassels. Also, $r_{G}$ and $r_{F}$ were smaller in the subpopulation selected for decreasing ear height. In general, a high correlation between $\mathrm{PH}$ and $\mathrm{EH}$ has been reported by many authors. Estimates of the additive genetic correlation $\left(r_{A}\right)$ and phenotypic correlation summarized by Moraes (1989) averaged 0.82 and 0.78 , respectively. Also, Hallauer \& Miranda Filho (1995) presented a high average genetic correlation of the order of 0.81 . Miranda Filho \& Andrade (2000) reported on estimates of $r_{A}$ and $r_{F}$ of 0,842 and 0.803 between $\mathrm{PH}$ and $\mathrm{EH}$ in the base population ESALQ-PB1.

\section{Correlation between plant height (PH) and ear height (EH) with tassel traits (TB, and TL)}

The correlation coefficients between $\mathrm{PH}$ and $\mathrm{EH}$ with tassel branch number were always positive but not consistent among sub-populations. The highest correlations of EH with TB were observed with inbred progenies. Also, for both inbred and non-inbred progenies in Piracicaba the genetic correlation was higher in the sub-population selected for larger tassels. However, in Rio Verde, the highest positive correlation (0.301) was for EH x TB in the sub-population (T-). In general, correlation coefficients between EH and TB were higher than for $\mathrm{PH}$ and TB. Estimates of $r_{A}$ and $r_{F}$ in the base population ESALQ-PB1 were 0.379 and 0.339 for $\mathrm{PH} \times \mathrm{TB}$ and 0.436 and 0.382 for EH x TB, respectively (Miranda Filho \& Andrade, 2000). The correlation of $\mathrm{PH}$ and $\mathrm{EH}$ with tassel length (TL) was estimated in only three and two sub-populations, respectively, and the estimates of $r_{G}$ were all positive and above 0.40, except for $\mathrm{PH} \times \mathrm{TL}$ in the sub-population ESALQ-PB1 $(T+)$ with inbred progenies $\left(r_{G}=0.127\right)$. Estimates of $r_{A}$ in the base population ESALQ-PB1 were 0.273 and 0.101 for $\mathrm{PH} \times \mathrm{TL}$ and $\mathrm{EH} \times \mathrm{TB}$, respectively (Miranda Filho \& Andrade, 2000).

\section{Correlation between plant height $(\mathrm{PH})$ and ear height (EH) with ear yield (EW)}

The association of plant height and ear height with yield tends to be always positive. Hallauer \& Miranda Filho (1995) reported genetic correlation of 0.26 and 0.31 for the combinations $\mathrm{PH} \times \mathrm{EW}$ and $\mathrm{EH} \times \mathrm{EW}$, respectively, on the average of 23 experiments. The association of these traits in our experiments comprised only non-inbred progenies, where $r_{G}$ varied from 0.087 to 0.503 among subpopulations. EH showed higher correlation with EW than $\mathrm{PH}$, and differences were larger in the sub-populations divergently selected for ear height. When looking to the sub-populations divergently selected for tassel size, a higher genetic correlation of $\mathrm{PH}$ and $\mathrm{EH}$ with $\mathrm{EW}$ was observed in ESALQ-PB1 $(T+)$. Estimates of $r_{A}$ in the base population ESALQ-PB1 were 0.594 and 0.506 for $\mathrm{PH} \times \mathrm{EW}$ and $\mathrm{EH} \times \mathrm{EW}$, respectively (Miranda Filho \& Andrade, 2000).

\section{Correlation between tassel traits (TB, TL) and EW}

The genetic correlation coefficients between TB and $T L$ were low but negative $\left(r_{G}=-0.015\right)$ in ESALQ-PB1 $(T+)$ and positive $\left(r_{G}=0.232\right)$ in ESALQ-PB1 $(T-)$, the two sub-populations representing the divergent selection for tassel size. The later was closer to the $r_{A}$ estimate $(0.217)$ 
TABLE 3 - Observed means for six traits* in sub-populations at two locations (Piracicaba, SP and Rio Verde, GO).

\begin{tabular}{lclrrrcc}
\hline \multicolumn{1}{c}{ Sub-population } & Progeny & \multicolumn{1}{c}{ Location } & PH & EH & TB & EW & TL \\
\hline ESALQ-PB1 (T+) & FS & PIRACICABA & 197.0 & 107.9 & 35.1 & 147.8 & 42.0 \\
ESALQ-PB1 (T+) & FS & RIO VERDE & 201.9 & 113.4 & 43.0 & - & - \\
ESALQ-PB1 (T-) & FS & PIRACICABA & 187.6 & 87.7 & 7.4 & 139.9 & 41.8 \\
ESALQ-PB1 (T-) & FS & RIO VERDE & 189.5 & 91.3 & 8.9 & - & - \\
ESALQ-PB1 (E+) & FS & PIRACICABA & 237.4 & 138.6 & 22.5 & 170.9 & - \\
ESALQ-PB1 (E+) & FS & RIO VERDE & 221.5 & 128.6 & 23.1 & - & - \\
ESALQ-PB1 (E-) & FS & PIRACICABA & 165.2 & 64.1 & 14.3 & 130.0 & - \\
ESALQ-PB1 (E-) & FS & RIO VERDE & 159.8 & 70.3 & 18.3 & - & - \\
ESALQ-PB1 (T+) & S1 & PIRACICABA & 165.7 & 97.8 & 32.2 & - & 40.5 \\
ESALQ-PB1 (T-) & S1 & PIRACICABA & 159.6 & 76.4 & 6.3 & - & 38.2 \\
Check & & PIRACICABA & 169.7 & 85.2 & 19.4 & 194.9 & 43.6 \\
Check & & RIO VERDE & 184.8 & 88.5 & 15.7 & - & - \\
\hline${ }^{*}$ PH- plant height $(\mathrm{cm})$, EH- ear height (cm), TB- tassel branch number, EW- ear weight (g/plant) and & TL- tassel length (cm).
\end{tabular}

TABLE 4 - Estimates of the coefficients of genetic $\left(r_{G}\right.$, upper) and phenotypic $\left(r_{F}\right.$, lower) correlation in combinations of six traits in sub-populations of ESALQ-PB1 at two locations.

\begin{tabular}{|c|c|c|c|c|c|c|}
\hline \multicolumn{7}{|c|}{ Sub-populations* } \\
\hline & $T_{+F}$ & $T_{F}$ & $\mathrm{E}_{+\mathrm{F}}$ & $E_{-F}$ & $T_{+S}$ & $T_{-S}$ \\
\hline \multicolumn{7}{|c|}{ Piracicaba (SP) } \\
\hline \multirow[t]{2}{*}{ PHxEH } & 0.793 & 0.809 & 0.838 & 0.740 & 0.789 & 0.870 \\
\hline & 0.783 & 0.781 & 0.822 & 0.717 & 0.775 & 0.820 \\
\hline \multirow[t]{2}{*}{ PHxTB } & 0.135 & 0.020 & 0.041 & 0.088 & 0.092 & 0.160 \\
\hline & 0.184 & 0.053 & 0.234 & 0.214 & 0.101 & 0.218 \\
\hline \multirow{2}{*}{ PHxEW } & 0.195 & 0.087 & 0.231 & 0.342 & - & - \\
\hline & 0.174 & 0.122 & 0.361 & 0.314 & - & - \\
\hline \multirow[t]{2}{*}{ PHXTL } & 0.438 & - & - & - & 0.127 & 0.581 \\
\hline & 0.252 & - & - & - & 0.004 & 0.455 \\
\hline \multirow[t]{2}{*}{ EHxTB } & 0.192 & 0.037 & 0.167 & 0.241 & 0.668 & 0.347 \\
\hline & 0.205 & 0.158 & 0.370 & 0.285 & 0.210 & 0.326 \\
\hline \multirow[t]{2}{*}{ EHxEW } & 0.293 & 0.176 & 0.388 & 0.503 & - & - \\
\hline & 0.033 & 0.199 & 0.346 & 0.388 & - & - \\
\hline \multirow[t]{2}{*}{ EHxTL } & 0.421 & - & - & - & - & 0.439 \\
\hline & 0.082 & - & - & - & - & 0.281 \\
\hline \multirow[t]{2}{*}{ TBxEW } & -0.022 & 0.456 & 0.208 & 0.137 & - & - \\
\hline & 0.010 & 0.118 & 0.223 & 0.287 & - & - \\
\hline \multirow[t]{2}{*}{ TBxTL } & -0.015 & 0.232 & - & - & - & -0.014 \\
\hline & -0.010 & 0.034 & - & - & - & 0.071 \\
\hline \multirow[t]{2}{*}{ EWxTL } & 0.027 & - & - & - & - & - \\
\hline & 0.008 & - & - & - & - & - \\
\hline \multicolumn{7}{|c|}{ Rio Verde (GO) } \\
\hline \multirow[t]{2}{*}{ PHxEH } & 0.843 & 0.764 & 0.805 & 0.755 & - & - \\
\hline & 0.812 & 0.911 & 0.675 & 0.703 & - & - \\
\hline \multirow[t]{2}{*}{ PHхTB } & 0.127 & 0.077 & 0.041 & 0.040 & - & - \\
\hline & 0.041 & 0.085 & 0.234 & 0.102 & - & - \\
\hline \multirow[t]{2}{*}{ EHxTB } & 0.065 & 0.301 & 0.151 & 0.132 & - & - \\
\hline & 0.117 & 0.272 & 0.309 & 0.157 & - & - \\
\hline
\end{tabular}

${ }^{{ }^{*} T_{+F}}:$ ESALQ-PB1 (T+)FS $; T_{-F}:$ ESALQ-PB1 (T-)FS; $E_{+F}:$ ESALQ-PB1 (E+)FS; $E_{-F}:$ ESALQ-PB1 (E-)FS; $T_{+S}:$ ESALQ-PB1 $\left(T_{+}\right) S_{1} ; T_{-S}:$ ESALQ-PB1 (T-)S, 
in the base population ESALQ-PB1 (Miranda Filho \& Andrade, 2000). The genetic correlation TBxEW was calculated only for full-sib progenies and was small negative $(-0.022)$ in ESALQ-PB1 $\left(T_{+}\right)$and positive $(0.137$ to 0.456 ) in the other three sub-populations. In a study with the same sub-populations in the preceding cycle of divergent selection, Araújo (1992) found the same pattern of correlation between TB and EW. The only $r_{G}$ estimate for TL $x$ EW was in the sub-population ESALQ-PB1 $(T+)$ and was small positive (0.027). Apparently, divergent selection for tassel size and ear height affected the original pattern of correlation between tassel traits and ear yield because all the estimates depart from the $r_{A}$ estimates of 0.207 and 0.216 for TB $\times E W$ and TL $x E W$, respectively, as reported by Miranda Filho \& Andrade (2000) for the base population ESALQ-PB1. Falconer (1964) emphasized that selection may change significantly the pattern of correlation between traits. However, the pattern of correlation between tassel size and yield depends also on the effect of environment and tends to be positive under favorable environments (Soares Filho, 1987).

Generally the coefficients of genetic and phenotypic correlation differed substantially from the estimates in the base population ESALQ-PB1 before divergent selection for tassel size and ear placement (Miranda Filho \& Andrade,2000). Divergent selection affected the correlation between traits under unpredicted and varying magnitudes.

\section{REFERENCES}

AGUILAR MORÁN, J.F. Avaliação do potencial genético de linhagens e respectivos testadores obtidos de duas populações de milho (Zea mays L.). Piracicaba, 1984. 118p. Dissertação (Mestrado) - Escola Superior de Agricultura Luiz de Queiroz, Universidade de São Paulo.

ANDERSON, I.C. Plant characteristics that affect yield. In: ANNUAL HYBRID CORN INDUSTRY-RESEARCH CONFERENCE, 22., Washington, 1967. Proceedings. Washington, 1967. p.71-73.

ARAÚJO, P.M. Variabilidade genética em sub-populações de milho (Zea mays L.) obtidas por seleção divergente. Piracicaba, 1992. 153p. Dissertação (Mestrado) - Escola Superior de Agricultura Luiz de Queiroz, Universidade de São Paulo.

AYALA OSUNA, J.; ARAÚJO, S.M.C.; BANZATO, D.A. Avaliação do tamanho do pendão em relação a alguns caracteres agronômicos em duas populações de milho. In: CONGRESSO NACIONAL DE MILHO E SORGO, 15., Maceió, 1984. Anais. Brasília: EMBRAPA, CNPMS, 1986.

BRUNINI, O.; ALFONSI, R.R.; PAES DE CAMARGO, M.B. Efeito dos elementos climáticos no desenvolvimento da cultura do milho. In: SIMPÓSIO SOBRE A PRODUTIVIDADE DO MILHO, Londrina, 1983. Anais. Londrina: IAPAR, 1983.

DONALD, C.M. The breeding of crop ideotypes. Euphytica, v.17, p.385-403, 1968.

FAKOREDE, M.A.B.; MOCK, J.J. Changes in morphological and physiological traits associated with recurrent selection for grain yield in maize. Euphytica, v.27, p.397-409, 1978.

FALCONER, D.S. Introduction to quantitative genetics. 2.ed. New York: Ronald Press, 1964. 365p.
FARIAS NETO, A.L.; MIRANDA FILHO, J.B. Inbreeding in subpopulations of maize divergently selected for tassel size and ear height. Scientia Agricola, v.57, p.487-490, 2000.

GERALDI, I.O.; MIRANDA FILHO, J.B.; VENCOVSKY, R. Estimates of genetic parameters for tassel characters in maize (Zea mays L.) and breeding perspectives. Maydica, v.30, p.114, 1985.

HALLAUER, A.R.; MIRANDA FILHO, J.B. Quantitative genetics in maize breeding. 2.ed. Ames: lowa State University Press, 1995. 468p.

HUNTER, R.B.; DAYNARD, T.B.; HUME, D.J.; TANNER, J.W.; CURTIS, J.O; KANNEMBERG, L.W. Effect of tassel removal on grain yield of corn (Zea mays L.). Crop Science, v.9, p.405406, 1973.

LEONARD, W.A.; KIESSELBACH, T.A. The effect of the removal of tassels on the yield of corn. Agronomy Journal, v.24, p.514516, 1932.

LORDELO, J.A.C. Parâmetros genéticos nas populações de milho Piranão-VD2 e Piranão-VF1. Piracicaba: ESALQ/USP, 1982.

LORDELO, J.A.C.; MIRANDA FILHO, J.B. Correlações genéticas e fenotípicas entre caracteres em duas populações de milho braquítico. Relatório Científico do Departamento de Genética, ESALQ/USP, v.15, p.104-108, 1981.

MIRANDA FILHO, J.B. Cruzamentos dialélicos e síntese de compostos de milho (Zea mays L) com ênfase na produtividade e no porte da planta. Piracicaba, 1974. p. 164. Tese (Doutorado) - Escola Superior de Agricultura Luiz de Queiroz, Universidade de São Paulo.

MIRANDA FILHO, J.B.; ANDRADE, J.A.C. Quantitative variation in the maize population ESALQ-PB1. Piracicaba: USP/ESALQ. Depto de Genética, 2000. n.p. /não publicado/ MOCK, J.J.; PEARCE, R.B. An ideotype of maize. Euphytica, v.24, p.613-623, 1975.

MORAES, M.L.T. Estimativas de parâmetros genéticos para os caracteres: produção de grãos, altura da planta e altura da espiga em populações de milho. Piracicaba: ESALQ/USP, Depto. de Genética, 1989. 40p.

OBILANA, A.T.; HALLAUER, A.R. Estimation of variability of quantitative traits in BSSS by using unselected maize inbred lines. Crop Science, v.14, p. 99-103, 1974.

PATERNIANI, E. Origem e comportamento do milho Piranão. Relatório Científico do Departamento de Genética, ESALQ/USP, v.8, p.104-108, 1974.

PATERNIANI, E. Influence of tassel size on ear placement in maize (Zea mays L.). Maydica, v.26, p.85-91, 1981.

SAMPAIO, N.F. Propriedades genéticas e potencial para o melhoramento dos compostos de milho (Zea mays L) ESALQPB4 e ESALQ-PB5. Piracicaba, 1986. 105p. Dissertação (Mestrado) - Escola Superior de Agricultura Luiz de Queiroz, Universidade de São Paulo.

SOARES FILHO, W.S. Características fenotípicas e genéticas das populações de milho (Zea mays L.) braquítico PiranãoVD2B e Piranão-VF1B. Piracicaba, 1987. 185p. Tese (Doutorado) - Escola Superior de Agricultura Luiz de Queiroz, Universidade de São Paulo.

SOUZA JR., C.L.; GERALDI, I.O; ZINSLY, J.R. Influence of tassel size on the expression of prolificacy in maize (Zea mays L.) Maydica, v.30, p.321-328, 1985.

VENCOVSKY, R. Herança quantitativa. In: PATERNIANI, E.; VIÉGAS, P. (Ed.) Melhoramento e produção do milho. Campinas: Fundação Cargill, 1978.

VENCOVSKY, R.; BARRIGA, P. Genética biométrica no fitomelhoramento. Ribeirão Preto: SBG, 1992. 496p.

WITTNER, S.H. Maximum production capacity of food crops. Bioscience, v.24, p.216-224, 1974.

Received October 13, 1999 